Dorota Moroń

Uniwersytet Wrocławski

\title{
Ocena wpływu inwestycji społecznych w literaturze naukowej*
}

DOI: $10.19195 / 1643-0328.23 .9$

Słowa kluczowe: polityka społeczna, inwestycje społeczne, wpływ inwestycji społecznych

\section{Wprowadzenie}

Inwestycyjna polityka społeczna to nowy paradygmat we współczesnej polityce społecznej, kładący nacisk na traktowanie polityki społecznej jako inwestycji, lokaty środków, które zwrócą się w przyszłości - zarówno w wymiarze społecznym, jak i ekonomicznym. Podejście inwestycyjne odchodzi od traktowania polityki społecznej jako kosztu i zwraca uwagę na fakt, że podejmowane w jej ramach działania mogą przynosić profity bezpośrednim beneficjentom, jak również całemu społeczeństwu i państwu. Takie ujęcie jest szczególnie istotne w perspektywie rekonstrukcji państwa opiekuńczego i dążeń do ograniczania wydatków na cele społeczne, traktowanych jako bezproduktywne i obciążające gospodarkę ${ }^{1}$. Wskazuje bowiem na zasadność realizacji polityki społecznej i możliwość pogodzenia celów społecznych i gospodarczych ${ }^{2}$.

Inwestycjami społecznymi określić można więc takie rozwiązania z zakresu polityki społecznej, które - dobrze zaplanowane - będą skuteczne, efektywne, zmaksymalizują skutki społeczne, przyniosą społeczny postęp i zmniejszą przyszłe koszty społeczne ${ }^{3}$. Inwestycje społeczne lokowane są w tych obszarach polityki społecznej, które związane są z rozwojem zasobów ludzkich i podnoszeniem jakości kapitału ludzkiego, jak też tworzeniem możliwości w zakresie ochrony i wykorzystywania kapitału ludzkiego. Należą

* Artykuł powstał w wyniku realizacji projektu badawczego Innovative Social Investment Strengthening Communities in Europe, InnoSI, nr 649189, finansowanego przez Komisję Europejską z programu Horizon 2020-EU.3.6.

${ }^{1}$ B. Nolan, What use is 'social investment'?, „Journal of European Social Policy” 23, 2013, nr 5, s. 460-461.

2 N. Morel, B. Palier, J. Palme, Paradygmat inwestycji społecznych: w poszukiwaniu nowego modelu ekonomicznego i mobilizacji politycznej, [w:] Polityka społeczna jako inwestycja, red. iidem, Warszawa 2015, s. 356.

3 I. Nicaise, W. Schepers, Social Investment. The New Paradigm of EU Social Policy?, https://socialsecurity. belgium.be/sites/default/files/btsz-2-2013-nicaise-schepers-nl.pdf (dostęp: 23 października 2017). 
do nich przede wszystkim polityka edukacyjna, polityka szkolnictwa wyższego, rynku pracy, polityka w zakresie łączenia życia zawodowego i rodzinnego, włączenia społecznego czy aktywizacji społecznej. Polityka inwestycyjna ma również na celu zapewnienie stabilizacji i bezpieczeństwa społecznego ${ }^{4}$.

W swoim założeniu inwestycja, wiążąca się z przeznaczeniem środków na określone zadania, rezygnacją z bezpośredniej konsumpcji dóbr i usług, ma przynieść korzyści w przyszłości. Profity te uzasadnić mają ponoszone nakłady. W tej perspektywie istotna jest ocena wpływu inwestycji społecznych, która wykazać powinna zasadność podejmowania działań o charakterze inwestycyjnym.

Artykuł prezentuje wyniki badań dotyczących ocen wpływu inwestycji społecznych prezentowanych $\mathrm{w}$ literaturze naukowej. Celem jest analiza aspektów teoretycznych i wyników badań empirycznych nad wpływem inwestycji społecznych. Dla realizacji celu badawczego postawiono następujące pytania badawcze: 1. Jakie są przyczyny podejmowania analizy wpływu inwestycji społecznych?, 2. Jakie trudności wiążą się z oceną wpływu inwestycji społecznych?, 3. Jak oceniany jest wpływ inwestycji społecznych? Postawiona hipoteza zakłada, iż ocena wpływu inwestycji społecznych nie jest jednoznaczna, co w dużym zakresie wiąże się z trudnością zbudowania metodologii takiej oceny.

Odpowiedzi na postawione pytania badawcze, zawarte w kolejnych rozdziałach artykułu, pozwoliły na weryfikację postawionej hipotezy. W artykule wskazano na konieczność podejmowania badań nad wpływem inwestycji społecznych oraz przedstawiono trudności wiążące się z oceną wpływu rozwiązań inwestycyjnych. Zaprezentowano także przykłady pozytywnego oddziaływania inwestycji społecznych oraz braku wpływu inwestycji identyfikowane w badaniach empirycznych i przytaczane w literaturze naukowej.

Przedstawione w niniejszym artykule wyniki badań uzyskane zostały w ramach realizacji naukowego projektu badawczego Innovative Social Investment Strengthening Communities in Europe, InnoSI, nr 649189, finansowanego przez Komisję Europejską z programu Horizon 2020-EU.3.6.

W artykule wykorzystano metodę desk research. Analizie poddano literaturę przedmiotu $\mathrm{z}$ zakresu inwestycji społecznych zebraną $\mathrm{w}$ ramach przeprowadzonej kwerendy źródłowej. Objęto nią źródła, głównie recenzowane artykuły naukowe, monografie, raporty naukowe, wydane w latach 2000-2015, dotyczące teoretycznych aspektów inwestycji społecznych oraz praktyki wdrażania inwestycji, w szczególności w państwach europejskich. Źródeł poszukiwano przede wszystkim w elektronicznych bazach danych, jednakże wykorzystano także źródła z bibliotek uniwersyteckich. Ogółem analizie poddano około 170 publikacji zebranych przez polski zespół badawczy oraz dodatkowo 140 źródeł zebranych przez partnerów projektu. Szczegółowy opis metodologii przeprowadzonej kwerendy przedstawiono w raporcie Report on scientific literature review on the concept "Social Investment"

4 A. Hemerijck, Social Investment and Its Critics, [w:] The Uses of Social Investment, red. idem, Oxford 2017, s. 19.

5 A. Wiktorska-Święcka et al., Report on scientific literature review on the concept „Social Investment”, A deliverable of the project: Innovative Social Investment: Strengthening communities in Europe (InnoSI), European Commission - Horizon 2020, European Commission, Research Executive Agency, Brussels 2016, s. 9-13. 
Z przeprowadzonych badań wynika, że w literaturze naukowej tematyka analizy wpływu inwestycji społecznej nie jest zagadnieniem popularnym. W artykule zaprezentowano najistotniejsze wnioski wypływające z publikacji, które podejmują ten aspekt podejścia do inwestycji społecznych.

\section{Czy badanie wpływu inwestycji społecznych jest potrzebne?}

Badania wpływu inwestycji społecznych podejmowane są głównie w związku z potrzebami praktycznymi, a nie tylko analizami naukowymi. W kontekście praktyki polityki społecznej ocena wpływu inwestycji społecznych jest szczególnie istotna, daje bowiem podstawy do podejmowania decyzji co do wdrażania - lub nie - określonych rozwiązań.

Do podjęcia decyzji w sprawie wdrażania nowych rozwiązań, nie tylko inwestycji, niezbędne jest uprawdopodobnienie ich skuteczności. Analiza wpływu inwestycji, bazująca na rozważaniach teoretycznych, analizach empirycznych bądź ocenach wdrożonych w praktyce rozwiązań, pozwala na wykazanie faktycznej skuteczności i efektywności działań lub uwiarygodnienie potencjalnego oddziaływania.

Sukces inwestycji społecznych jako idei politycznej w dużym stopniu zależy od tego, czy możliwe będzie przekonanie decydentów politycznych (polityków, rządu, parlamentu), jak również obywateli - wyborców, że warto inwestować, wydawać pieniądze, aby w przyszłości nakłady zaprocentowały. W tym kontekście niezbędne są wyniki badań, które potwierdzają skuteczność inwestycji i mogą być podstawą do podjęcia decyzji o wdrażaniu takich rozwiązań ${ }^{6}$.

Wpływ inwestycji społecznych jest szczególnie ważny w związku z faktem, że rozwiązania inwestycyjne są kosztowne. Nie oznacza to jednocześnie, że są droższe np. od rozwiązań o charakterze redystrybucyjnym, ale w związku z ograniczeniami budżetowymi dąży się współcześnie do szukania oszczędności w polityce społecznej, m.in. poprzez tworzenie i wdrażanie tańszych rozwiązań lub rezygnację z działań o charakterze społecznym. Ponoszenie kosztów musi mieć więc swoje uzasadnienie w skuteczności wdrażanych rozwiązań.

\section{Trudność oceny wpływu inwestycji społecznych}

Potrzeba oceny wpływu inwestycji społecznych powoduje, że podejmowane są liczne analizy oceniające wpływ projektowanych i wdrażanych rozwiązań. Nie oznacza to braku kontrowersji i problemów wiążących się z ową oceną oraz powodujących, że prezentowane wyniki badań są dyskusyjne, trudne do obiektywnego sprawdzenia i potwierdzenia.

Kluczowa trudność wiążąca się z oceną wpływu inwestycji wynika z samego założenia polityki inwestycyjnej - ponoszenia nakładów, które zaprocentują w przyszłości.

${ }^{6}$ G. Bonoli, Comment on Anton Hemerijck making social investment work, „Sociologica” 1, 2012, https:// www.rivisteweb.it/download/article/10.2383/36891 (dostęp: 25 listopada 2015). 
Perspektywa przyszłości oznacza, że efekty działań odnotowane mogą być zwykle tylko w długim okresie. Oceny krótkookresowe lub prognostyczne bardzo często w ogóle nie są miarodajne. Natomiast wpływ inwestycji społecznych, szczególnie w dłuższym okresie, może być zmienny, w dużym stopniu zależy też od kontekstu i realizacji ${ }^{7}$.

Można powiedzieć, że idea inwestycji społecznych opiera się na obietnicy, iż pieniądze wydane dziś zaprocentują w przyszłości ${ }^{8}$. Ten rodzaj wydatków niesie więc za sobą oczekiwanie spłaty części lub całości nakładów przez tych, w których dzisiaj inwestujemy. Warunki wdrażania i realizacji inwestycji społecznych mogą się jednak zmieniać w czasie, dotyczy to także sytuacji społeczno-gospodarczej, stąd porównywalność rezultatów i wpływu inwestycji jest ograniczona.

Anton Hemerijck zwraca szczególną uwagę na fakt, że inwestycje społeczne wdrażane są w określonym kontekście społeczno-gospodarczym oraz są elementem polityki społecznej państwa, obejmującej określony zakres działań inwestycyjnych oraz redystrybucyjnych, co wpływa na faktyczne oddziaływanie inwestycji społecznych ${ }^{9}$. Takie same działania inwestycyjne zastosowane $\mathrm{w}$ dwóch różnych państwach, o różnych systemach społeczno-gospodarczych i rozwiązaniach z zakresu polityki społecznej przynieść mogą zupełnie inne efekty. Ocena wpływu inwestycji musi więc uwzględniać kontekst działań, co czyni ją szczególnie skomplikowaną.

Hemerijck podkreśla też, że na oddziaływanie inwestycji społecznych w dużym stopniu wpływa spójność prowadzonych działań ${ }^{10}$. Dotyczy to nie tylko spójności działań w ramach samych inwestycji społecznych, ale całej polityki społecznej, jak również innych polityk, które wpływają na powodzenie inwestycji społecznych. Dotyczy to choćby regulacji z zakresu polityki gospodarczej czy prawa pracy. Rozwiązania takie mogą zachęcać do działań promowanych przez strategie inwestycyjne albo do nich zniechęcać ${ }^{11}$. Giuliano Bonoli wskazuje w tym kontekście na kraje Europy Południowej, w których, wobec problemów gospodarczych i niepewności ekonomicznej, inwestycje społeczne nie są wystarczającą strategią umożliwiającą rozwój społeczny i ekonomiczny ${ }^{12}$. Argumentuje przy tym, że trudność oceny wpływu inwestycji społecznych wiąże się z faktem, iż na ich efektywność duży wpływ ma skuteczność działań administracji publicznej ${ }^{13}$. Dla przykładu: aktywna polityka rynku pracy wymaga wydajnych służb zatrudnienia. Budowa skutecznej administracji jest konieczna, a jednocześnie kosztowna, co w niektórych krajach znacząco ogranicza możliwości wdrażania inwestycji społecznych i może ograniczać ich wpływ.

Trudność oceny wpływu inwestycji społecznych wiąże się z określeniem metodologii jej przeprowadzenia, a więc z wyborem metod i sposobów oceny. Skomplikowany jest

7 E. Carter, A. Whitworth, Creaming and parking in quasi-marketised welfare-to-work schemes: Designed out of or designed in to the UK work programme?, "Journal of Social Policy” 44, 2015, nr 2.

${ }^{8}$ G. Bonoli, op. cit.

9 Zob. A. Hemerijck, Changing Welfare States, Oxford 2013.

10 Zob. ibidem.

11 Zob. ibidem.

12 G. Bonoli, op. cit.

13 Ibidem. 
pomiar skutków inwestycji społecznych (szczególnie skutków społecznych), istnieje bowiem wiele alternatywnych metodologii pomiaru, często zaś dokonywana ocena jest pobieżna, bazuje na wybranych informacjach i danych społecznych, bez stosowania oceny ryzyka czy budowania wskaźników oddziaływania społecznego ${ }^{14}$. Michael J. Roy, Neil McHugh, Clementine Hill O'Connor wskazują w tym kontekście, że inwestycje społeczne są przedmiotem różnych, często konkurencyjnych konceptualizacji, a różna metodologia oceniania skuteczności inwestycji wpływa na kwestie istnienia lub braku dowodów na skuteczność oddziaływań ${ }^{15}$.

Inwestycje społeczne często wiążą się z osiąganiem celów o charakterze niemierzalnym. Rezultaty projektów społecznych są możliwe do opisania, trudniejsze zaś do zmierzenia, a jeszcze trudniejsze do oszacowania $\mathrm{w}$ wartościach ekonomicznych. Wyzwania pojawiają się, jeśli chodzi o szacowanie korzyści niematerialnych czy zmian społecznych. W tym kontekście pojawiają się propozycje różnorodnych metod ewaluacji ekonomicznej społecznych korzyści z realizacji polityk publicznych oraz wdrażania programów i projektów społecznych ${ }^{16}$. Każda z nich ma swoje zalety, ale i ograniczenia.

Współcześnie głównym kryterium ewaluacyjnym projektów społecznych jest ich skuteczność oznaczająca poziom osiągnięcia korzyści społecznych w trakcie i po ich realizacji. Ocena skuteczności zmierza do tego, aby stwierdzić, czy wybrane metody działania przyczyniły się do osiągnięcia założonych celów, rozwiązania problemów oraz czy zastosowane metody i środki są w zgodzie z potrzebami i wartościami beneficjentów danego projektu. Oszacowanie skuteczności projektu społecznego stanowi zatem ocenę społecznego wpływu (social impact), jaki dany projekt wywiera na jego odbiorców oraz ich otoczenie środowiskowe, społeczne i gospodarcze. W kontekście wdrażania projektów społecznych w oparciu o paradygmat inwestycji społecznych coraz większe znaczenie przypisuje się jednak ich efektywności. O efektywności projektu społecznego można mówić w sytuacji, w której uzyskane efekty danego projektu przewyższają koszty poniesione na jego realizację. Można ją zmierzyć, porównując nakłady finansowe lub zmonetaryzowane (inputs) z osiągniętymi efektami - produktami lub rezultatami (outputs, outcomes). Wybór metodologii pomiaru determinuje ocenę wpływu inwestycji społecznych, a ze względu na różnorodność rozwiązań bardzo często oceny są dyskusyjne.

Ocena wpływu inwestycji społecznych może być dokonywana z perspektywy inwestora (państwa, innych podmiotów), osób, które są odbiorcami działań inwestycyjnych, oraz ich otoczenia. Uwzględnienie wszystkich istotnych perspektyw oceny lub wybór jednej kluczowej również wiąże się z problemami i koniecznością podjęcia arbitralnych decyzji.

Ważną kwestią jest dostęp do danych i informacji umożliwiających ocenę wpływu. Bardzo często informacje te są tylko fragmentaryczne i nie dają możliwości pełnej oceny całej inwestycji społecznej we wszystkich jej aspektach.

14 R. Hazenberg, F. Seddon, S. Denny, Intermediary perceptions of investment readiness in the UK social investment market, „Voluntas” 26, 2015.

15 M.J. Roy, N. McHugh, C.H. O'Connor, Social innovation: Worklessness, welfare and well-being, „Social Policy and Society" 13, 2014, nr 3.

16 Zob. D. Moroń, M. Klimowicz, Zastosowanie stopy społecznego zwrotu z inwestycji (SROI) jako wskaźnika mierzenia efektywności projektów społecznych, „Wrocławskie Studia Politologiczne” 21, 2016. 
Wskazane trudności i kontrowersje nie oznaczają, że ocena wpływu inwestycji społecznej nie ma sensu. Przy projektowaniu i przeprowadzaniu ocen istotna jest świadomość tych ograniczeń. Ważne jest przedstawianie przeprowadzanych ocen w jak najbardziej szczegółowy i dokładny sposób - aby możliwe było poznanie wszystkich przyjętych przy dokonywanej ocenie założeń.

\section{Czy inwestycje społeczne mają pozytywny wpływ na życie społeczne?}

W swoim założeniu inwestycje społeczne mają przynosić pozytywne skutki społeczne, a dodatkowo również ekonomiczne. Zainwestowane - poprzez realizację działań z zakresu polityki społecznej - środki finansowe powinny dostarczać zysków inwestorom $\mathrm{w}$ formie pozytywnego wpływu na życie społeczne i gospodarkę.

$\mathrm{W}$ literaturze naukowej wpływ inwestycji społecznych oceniany jest niejednoznacznie. $Z$ jednej strony wskazywane są efekty pozytywne, $z$ drugiej jednak pojawiają się zastrzeżenia co do skuteczności oddziaływania inwestycji społecznych czy braku adekwatności działań do ponoszonych kosztów.

Przedstawiany pozytywny wpływ inwestycji społecznych obejmuje zarówno pozytywne skutki społeczne prowadzonych działań, jak i efekty gospodarcze, takie jak wzrost i rozwój gospodarczy, budżetowe, w postaci mniejszych wydatków na działania z zakresu polityki społecznej, oraz fiskalne - większe wpływy z podatków. Hemerijck, syntetyzując, podkreśla, że „wdrażanie inwestycji społecznych koresponduje z wysokim poziomem udziału kobiet i mężczyzn w życiu zawodowym, wysoką wydajnością, niską inflacją i nadwyżkami budżetowymi, bez dużego wzrostu nierówności" ${ }^{17}$.

Pozytywny wpływ inwestycji społecznych w sferze społecznej mocno podkreślany jest $\mathrm{w}$ obszarze rynku pracy, szczególnie $\mathrm{w}$ odniesieniu do wzrostu zatrudnienia, ale również redukcji bezrobocia oraz zwiększania szans osób bezrobotnych na rynku pracy. Szczególne znaczenie mają w tym zakresie inwestycje społeczne realizowane w ramach aktywnej polityki rynku pracy oraz polityki wczesnej edukacji i opieki nad dziećmi. Te ostatnie sprzyjają wzrostowi zatrudnienia kobiet, co zwiększa równość szans na rynku pracy ${ }^{18}$.

Duże znaczenie inwestycji społecznych wskazywane jest także w zakresie wpływu na kapitał ludzki - odnośnie do zwiększania wiedzy, umiejętności i kompetencji jednostek, w tym niezbędnych na rynku pracy $\mathrm{w}$ gospodarce opartej na wiedzy. W tym kontekście istotne są oddziaływania w ramach polityki wczesnej edukacji i opieki nad dziećmi, systemu edukacji oraz aktywnej polityki rynku pracy. Uwaga zwrócona jest

17 A. Hemerijck, Changing Welfare States..., s. 379.

18 P. Taylor-Gooby, J.M. Gumy, A. Otto, Can 'new welfare' address poverty through more and better jobs?, „Journal of Social Policy” 44, 2015, nr 1; A. Hemerijck, Changing Welfare States...; idem, Dwie czy trzy fale przemian państwa opiekuńczego?, [w:] Polityka społeczna jako inwestycja...; S.-H. Ahn, S.-W. Kim, Social investment, social service and the economic performance of welfare states, „International Journal of Social Welfare" 24, 2015. 
również na kapitał społeczny, który także ma wpływ na produktywność jednostek i ich sukces na rynku pracy. Ważną rolę odgrywają tu działania na rzecz równości szans edukacyjnych i wsparcie rozwoju jednostek ${ }^{19}$.

Inwestycje społeczne wskazuje się jako fundamentalne z perspektywy gospodarki opartej na wiedzy i wymogów stawianych pracownikom. Moira Nelson i John D. Stephens wykazują, że strategie inwestycyjne mają istotny wpływ na jakość kapitału ludzkiego oraz na zatrudnienie, szczególnie na zatrudnienie wysokiej jakości. Rolę odgrywają tu inwestycje zarówno w edukację, jak i w politykę rynku pracy ${ }^{20}$.

Inwestycje społeczne - w odróżnieniu od polityki redystrybucyjnej - kładą duży nacisk na usługi społeczne. Sang-Hoon Ahn i Soo-Wan Kim zwracają uwagę na efektywność strategii inwestycyjnej opartej na usługach społecznych. Z ich badań wynika, że rozwiązania redystrybucyjne mają negatywny wpływ na zatrudnienie, natomiast inwestycje oparte na usługach społecznych przynoszą pozytywne efekty w sferze rozwoju gospodarczego, ograniczają bezrobocie i zwiększają zatrudnienie ${ }^{21}$.

W literaturze naukowej zidentyfikować można również głosy dotyczące ograniczonego wpływu czy wręcz braku wpływu inwestycji społecznych na rozwiązywanie istotnych problemów społecznych. W tym kontekście szczególnie często podejmowany jest problem braku wpływu na rozwiązanie problemu ubóstwa, a także bezrobocia. Jest to istotne szczególnie w kontekście polityki Unii Europejskiej, która promuje inwestycje społeczne, a walkę z ubóstwem, wykluczeniem społecznym i bezrobociem czyni jednym z podstawowych celów działań w sferze społecznej, w tym oddziaływań o charakterze inwestycyjnym. Brak efektów (czy niezadowalające efekty) inwestycji społecznych jako narzędzia ograniczania ubóstwa stanowią kluczowy obszar krytycznego podejścia do inwestycji społecznych w literaturze naukowej ${ }^{22}$.

W literaturze naukowej podejmowane są również analizy przyczyn ograniczonej skuteczności polityki inwestycji społecznych w walce z ubóstwem. Autorzy wskazują w tym kontekście na fakt, że usługi publiczne realizowane $\mathrm{w}$ ramach paradygmatu inwestycji mają mniej redystrybucyjny charakter niż tradycyjne transfery pieniężne ${ }^{23}$. Związane jest to $\mathrm{z}$ faktem, że usługi mają zwykle bardziej egalitarny charakter niż transfery pieniężne, które $\mathrm{w}$ ramach walki $\mathrm{z}$ bezrobociem i ubóstwem kierowane są generalnie do

19 A. Hemerijck, Dwie czy trzy fale przemian państwa opiekuńczego?...; S. Gatt, L.S. Armeni, Educating practices at primary school level and new forms of positive welfare for families, „Social Policy and Society” 12, 2013, $\mathrm{nr} 4$; H. Solga, Education, economic inequality, and the promises of the social investment state, „Socio-Economic Review” 12, 2014, nr 2; H. Strandell, After-school care as investment in human capital from policy to practices, „Children \& Society” 27, 2013, nr 4.

${ }^{20}$ M. Nelson, J.D. Stephens, Czy strategie inwestycji społecznych są źródłem większej liczby miejsc pracy lepszej jakości?, [w:] Polityka społeczna jako inwestycja...

21 S.-H. Ahn, S.-W. Kim, op. cit.

22 P. Taylor-Gooby, J.M. Gumy, A. Otto, op. cit.; V. Corluy, F. Vandenbroucke, Individual Employment, Household Employment, and Risk of Poverty in the European Union. A Decomposition Analysis, [w:] Reconciling Work and Poverty Reduction. How Successful are European Welfare States?, red. B. Cantillon, F. Vandenbroucke, Oxford 2014; B. Cantillon, The paradox of the social investment state: Growth, employment and poverty in the Lisbon era, „Journal of European Social Policy” 21, 2011, nr 5.

23 B. Cantillon, op. cit. 
osób o najniższych dochodach ${ }^{24}$. Stąd być może oddziałują aktywizująco, jednakże nie rozwiązują problemu biedy. Można również wykazać skuteczność redystrybucyjną usług o charakterze inwestycyjnym - zależy to od całościowego ukierunkowania polityki inwestycyjnej i jej spójności ${ }^{25}$.

Problem skuteczności inwestycji wiąże się też z tym, że często osoby ubogie w mniejszym zakresie korzystają z rozwiązań inwestycyjnych, co przekłada się na ich niekorzystną sytuację. Bea Cantillon i Wim Van Lancker podają jako przykład politykę wczesnej edukacji i opieki nad dziećmi, której głównymi beneficjentami są dzieci z rodzin lepiej sytuowanych $^{26}$, co ma związek z konstrukcją zasad dostępności do tego systemu, np. opłatami, preferencjami dla pracujących.

Ważnym aspektem jest fakt, że wdrażanie paradygmatu inwestycji społecznych przy ograniczonych zasobach finansowych powoduje, iż środki przesuwane są $\mathrm{z}$ polityk o charakterze redystrybucyjnym do tych, które mają bardziej inwestycyjny charakter. Wskazać można w tym zakresie na przykład wsparcia osób bezrobotnych. Nacisk na programy aktywizacyjne często wiąże się z ograniczaniem zasiłków dla bezrobotnych, co zwiększa ryzyko ubóstwa osób bezrobotnych. Oczywiście samo wdrażanie programów aktywizacyjnych nie musi oznaczać automatycznie cięć wydatków socjalnych — jednakże ograniczone środki budżetowe oraz konieczność zwiększania nakładów na politykę zdrowotną i wydatki emerytalne powodują, że szuka się oszczędności w innych sferach polityki społecznej ${ }^{27}$.

Inwestycje społeczne na rynku pracy często powodują aktywizację osób biernych zawodowo, natomiast w mniejszym stopniu aktywizują osoby długotrwale bezrobotne, dotknięte również innymi problemami społecznymi, np. wykluczeniem społecznym, uzależnieniami ${ }^{28}$. One wymagają wieloaspektowych programów oddziaływań, w których aktywizacja zawodowa jest tylko jedną z form wsparcia.

W tym kontekście pojawia się też problem osób, które wymagają ochrony socjalnej i nie mogą - lub mogą tylko w bardzo ograniczonym zakresie - być zaktywizowane na rynku pracy, np. niepełnosprawnych. Jeśli ich sytuacja nie zostanie uwzględniona, to bardzo często ubóstwo takich osób się pogłębia ${ }^{29}$.

Bea Cantillon wskazuje na konieczność dalszych analiz empirycznych relacji między ubóstwem a inwestycjami społecznymi, głównie w związku z krótką perspektywą czasową dokonywanych aktualnie ocen rozwiązań inwestycyjnych. Jednocześnie argumentuje, że na podstawie zaprezentowanych danych wykazać można słabość inwestycji

24 B. Cantillon, W. Van Lancker, Three shortcomings of the social investment perspective, „Social Policy and Society" 12, 2013, nr 4; G. Verbist, M. Matsaganis, The Redistributive Capacity of Services in the European Union, [w:] Reconciling Work and Poverty Reduction...

25 W. Van Lancker, J. Ghysels, Who benefits? The social distribution of subsidized childcare in Sweden and Flanders, „Acta Sociologica” 55, 2012, nr 2.

26 B. Cantillon, W. Van Lancker, op. cit., s. 559-560.

27 F. Vandenbroucke, K. Vleminckx, Disappointing poverty trends: Is the social investment state to blame?, „Journal of European Social Policy” 21, 2011, nr 5.

28 B. Cantillon, op. cit.

29 B. Cantillon, W. Van Lancker, op. cit., s. 555-557. 
społecznych w sferze walki z ubóstwem. Nie oznacza to jednak, że polityka inwestycji społecznych powinna zostać zaniechana. Podkreśla też, że przejście od tradycyjnego państwa opiekuńczego, nastawionego na redystrybucję, do państwa inwestycji społecznych okazało się trudniejsze, niż oczekiwano. Inwestycje społeczne są potrzebne, jednakże uzupełnione powinny być działaniami o charakterze redystrybucyjnym. Odpowiednie zabezpieczenie społeczne i skuteczne programy redystrybucji społecznej są bowiem nieodłączną częścią każdej skutecznej strategii inwestycyjnej ${ }^{30}$.

\section{Podsumowanie}

Przedstawione w artykule rozważania dotyczące aspektów teoretycznych i wyników badań empirycznych nad wpływem inwestycji społecznych pozwalają pozytywnie zweryfikować hipotezę wskazującą, iż ocena wpływu inwestycji społecznych nie jest jednoznaczna, co w dużym zakresie wiąże się z trudnością zbudowania metodologii takiej oceny. Funkcjonowanie inwestycji społecznych w określonym kontekście społeczno-gospodarczym i wzajemny wpływ różnych rozwiązań z zakresu polityki społecznej powodują, że trudno ocenić efektywność inwestycji w oderwaniu od rzeczywistości społecznej. Ocena zależy też od przyjętej metodologii, a dodatkowo konieczne jest uwzględnienie czasowego zakresu oddziaływania, inwestycje w swoim założeniu mają bowiem przynosić efekty w długim okresie. Te ograniczenia są przez badaczy dostrzegane i uwzględniane przy stawianiu wniosków w zakresie wpływu inwestycji społecznych.

W literaturze prezentowane są zarówno przykłady pozytywnego oddziaływania inwestycji społecznych, jak i ograniczonego ich wpływu. Problem ten wymaga więc dalszych, pogłębionych badań, które przyniosłyby bardziej konkretne odpowiedzi co do zasadności wdrażania paradygmatu inwestycyjnego.

Podsumowując, wskazać można, że inwestycje społeczne prowadzą nie tylko do postępu społecznego, lecz opłacają się również z gospodarczego i podatkowego punktu widzenia. Pomimo zgłaszanych w literaturze naukowej wątpliwości wskazać można, że - dobrze zaplanowane i dostosowane do potrzeb określonych kategorii społecznych oraz kontekstu społeczno-gospodarczego - inwestycje społeczne przynoszą wiele pozytywnych skutków, choć automatycznie nie rozwiązują wszystkich problemów społecznych. Inwestycje przynoszą pozytywne skutki przede wszystkim w perspektywie średnio- i długoterminowej, stąd ich ocena musi uwzględniać perspektywę czasową. Należy jednocześnie zauważyć, że brak inwestycji społecznych również ma swoją cenę, a koszty zaniechanych inwestycji społecznych mogą być bardzo wysokie.

30 B. Cantillon, op. cit., s. 445; B. Cantillon, W. Van Lancker, op. cit., s. 561. 


\section{Bibliografia}

Ahn S.-H., Kim S.-W., Social investment, social service and the economic performance of welfare states, „International Journal of Social Welfare" 24, 2015.

Bonoli G., Comment on Anton Hemerijck making social investment work, „Sociologica” 1, 2012, https://www. rivisteweb.it/download/article/10.2383/36891 (dostęp: 25 listopada 2015).

Cantillon B., The paradox of the social investment state: Growth, employment and poverty in the Lisbon era, "Journal of European Social Policy" 21, 2011, nr 5.

Cantillon B., Van Lancker W., Three shortcomings of the social investment perspective, „Social Policy and Society" 12, 2013, $\mathrm{nr} 4$.

Carter E., Whitworth A., Creaming and parking in quasi-marketised welfare-to-work schemes: Designed out of or designed in to the UK work programme?, „Journal of Social Policy” 44, 2015, nr 2.

Corluy V., Vandenbroucke F., Individual Employment, Household Employment, and Risk of Poverty in the European Union. A Decomposition Analysis, [w:] Reconciling Work and Poverty Reduction. How Successful are European Welfare States?, red. B. Cantillon, F. Vandenbroucke, Oxford University Press, Oxford 2014.

Gatt S., Armeni L.S., Educating practices at primary school level and new forms of positive welfare for families, „Social Policy and Society” 12, 2013, nr 4.

Hazenberg R., Seddon F., Denny S., Intermediary perceptions of investment readiness in the UK social investment market, „Voluntas” 26, 2015.

Hemerijck A., Changing Welfare States, Oxford University Press, Oxford 2013.

Hemerijck A., Dwie czy trzy fale przemian państwa opiekuńczego?, [w:] Polityka społeczna jako inwestycja, red. N. Morel, B. Palier, J. Palme, Wydawnictwo Wyższej Szkoły Pedagogicznej im. Janusza Korczaka w Warszawie, Warszawa 2015.

Hemerijck A., Social Investment and Its Critics, [w:] The Uses of Social Investment, red. idem, Oxford University Press, Oxford 2017.

Morel N., Palier B., Palme J., Paradygmat inwestycji społecznych: w poszukiwaniu nowego modelu ekonomicznego i mobilizacji politycznej, [w:] Polityka społeczna jako inwestycja, red. iidem, Wydawnictwo Wyższej Szkoły Pedagogicznej im. Janusza Korczaka w Warszawie, Warszawa 2015.

Moroń D., Klimowicz M., Zastosowanie stopy społecznego zwrotu z inwestycji (SROI) jako wskaźnika mierzenia efektywności projektów społecznych, „Wrocławskie Studia Politologiczne” 21, 2016.

Nelson M., Stephens J.D., Czy strategie inwestycji społecznych są źródłem większej liczby miejsc pracy lepszej jakości?, [w:] Polityka społeczna jako inwestycja, red. N. Morel, B. Palier, J. Palme, Wydawnictwo Wyższej Szkoły Pedagogicznej im. Janusza Korczaka w Warszawie, Warszawa 2015.

Nicaise I., Schepers W., Social Investment. The New Paradigm of EU Social Policy?, https://socialsecurity.belgium.be/sites/default/files/btsz-2-2013-nicaise-schepers-nl.pdf (dostęp: 23 października 2017).

Nolan B., What use is 'social investment'?, „Journal of European Social Policy” 23, 2013, nr 5.

Roy M.J., McHugh N., O'Connor C.H., Social innovation: Worklessness, welfare and well-being, „Social Policy and Society" 13, 2014, nr 3.

Solga H., Education, economic inequality, and the promises of the social investment state, „Socio-Economic Review" 12, 2014, nr 2.

Strandell H., After-school care as investment in human capital - from policy to practices, „Children \& Society" 27, 2013, nr 4.

Taylor-Gooby P., Gumy J.M., Otto A., Can 'new welfare' address poverty through more and better jobs?, „Journal of Social Policy" 44, 2015, nr 1.

Van Lancker W., Ghysels J., Who benefits? The social distribution of subsidized childcare in Sweden and Flanders, „Acta Sociologica” 5, 2012, nr 2.

Vandenbroucke F., Vleminckx K., Disappointing poverty trends: Is the social investment state to blame?, „Journal of European Social Policy” 21, 2011, nr 5. 
Verbist G., Matsaganis M., The Redistributive Capacity of Services in the European Union, [w:] Reconciling Work and Poverty Reduction. How Successful are European Welfare States?, red. B. Cantillon, F. Vandenbroucke, Oxford University Press, Oxford 2014.

Wiktorska-Święcka A. et al., Report on scientific literature review on the concept „Social Investment”, A deliverable of the project: Innovative Social Investment: Strengthening communities in Europe (InnoSI), European Commission - Horizon 2020, European Commission, Research Executive Agency, Brussels 2016.

\section{Assessing impact of social investments in scientific literature}

Keywords: social policy, social investment, impact of social investment

Summary

The article presents the results of research on the assessing impact of social investments presented in the scientific literature. The aim is to analyze the theoretical aspects and the results of empirical research on the impact of social investment. The article presents the reasons for undertaking the impact of social investments' analysis, pointing to the need to validate the effectiveness of actions, to justify public spending and to convince policy makers of the investment implementation' necessity. The difficulties involved in assessing the impact of social investment in areas: methodology of assessing impact, time perspective and investment functioning in a specific socio-economic context are presented. The conducted analyzes allowed to demonstrate that the assessment of social investment is ambiguous - both the positive impact of investment (especially in the labor market and development of human capital) and its limited impact, mainly in the fight against poverty can be shown. The results of the research presented in this article were obtained in the framework of the scientific research project Innovative Social Investment Strenghtening Communities in Europe (InnoSi), financed by the European Commission from the Horizon 2020 Program. 